\title{
DEVELOPMENT IMPACTS OF GLOBALIZATION AND EDUCATION: EVIDENCE FROM THE ASIA-PACIFIC COUNTRIES
}

Pramila Neupane (Japan)

Jeet Bahadur Sapkota (Japan)

\begin{abstract}
This article compares globalization, education and development indicators of high-growth and low-growth countries in terms of their GDP per capita in the Asia-Pacific region from 1970 to 2010. Although development is multifaceted, this study mostly considers growth alone as the measure of development. It finds that countries with high level of education at 1970 have achieved high-growth along with rapid globalization over time, and vice versa. Similarly, panel data analysis of selected countries shows that globalization and education significantly enhance the growth. However, despite high level of education and globalization, the Philippines has surprisingly low-growth, high poverty and inequality, which indicates that good policies and institutions should complement globalization and educational base for rapid development.
\end{abstract}

KEYWORDS: Globalization, education, development, GDP per capita growth, AsiaPacific region

\section{INTRODUCTION}

Globalization is accelerated in recent decades affecting many aspects of development (while) bringing opportunities and threats to all nations. In this process, education can play a crucial role in optimizing the gains from globalization and ultimately achieving development goals, particularly in less developed countries. As the latest champions of globalization for their national development mainly come from the Asia-Pacific region, it is worthwhile to examine the impacts of globalization and education on development in the region. It is also relevant because of the fact that Asia-Pacific region also has a number of countries that are lagging behind in tapping globalization for national development. Thus, this study addresses the question that did the high economic growth of some countries in the Asia-Pacific region stem from their early expansion of school systems, and the rapid trend of globalization? It also explores how strong educational base is instrumental to withstand the increased competition and capitalize the opportunities offered by globalization for economic growth.

The remaining part of the article is organized as follows. Section 2 reviews the related literature; specifically on defining globalization and development, and impacts of globalization and education on development. Section 3 describes the methodical approaches. We follow two analytical approaches: comparative approach and econometric approach as explained in this section. Section 4 is the result of comparative 


\section{Crossing the Border: International Journal of Interdisciplinary Studies}

analysis, which simply compares the trends of globalization, education and some development indicators over the period of 1970 to 2010 selecting the five high-growth and five low-growth countries from the Asia-Pacific region. Section 5 shows the results from econometric analysis, which revealed a significant and positive impact of globalization and education on GDP per capita. Section 6 concludes the article.

\section{LITERATURE REVIEW}

The definition of globalization is complex, and there is rich and growing literature on development consequences of globalization (Sapkota, 2011). This article adopts a comprehensive definition of globalization developed by Dreher (2006). He defines,

Globalization is meant to describe the process of creating networks of connections among actors at multi-continental distances, mediated through a variety of flows including people, information and ideas, capital and goods. Globalization is conceptualized as a process that erodes national boundaries, integrates national economies, cultures, technologies and governance and produces complex relations of mutual interdependence. (p. 1092)

Dreher considered all possible elements for each dimension of globalization and developed the indexes of economic, social and political globalization by employing appropriate weights systematically for each component following the methodology of Gwartney and Lawson (2001), then introduced the "KOF index" of overall globalization, which is a composite index comprising 24 economic, social and political variables. The index is ranged from 0 as fully closed to 100 as fully open, and the data are available since 1970 in an annual basis for 208 of countries, which is updated annually by the KOF Swiss Economic Institute. KOF index is increasingly acknowledged by many social scientists worldwide, and hundreds of scholarly articles have already used the index. For further details of the KOF index see Dreher (2006, pp. 1092-1094).

Like globalization, 'development' also is a vague term. Development refers to a range of aspects, from purely economic terms to human rights and social justice, from the physical quality of life to happiness and human satisfaction. To simplify the study, however, this article uses growth rate of GDP per capita as a development indicator. It also considers infant mortality, poverty and inequality indicators to capture the key dimension of development.

The mainstream literature on globalization and development argues that globalization raises the living standard of all participants in the globalization process. While theory of international trade claims that increased trade raises the real incomes of all participating countries, accessing the superior technology embodied in goods or capital, or simply through intellectual exchange allows greater productivity gains in poorer countries (Urata \& Yokota, 1994). Similarly, international capital flows bring new technology and allow countries to tap into a larger savings pool, which also enhance growth in poorer countries (Arnal \& Hijzen, 2008).

Globalization has substantially changed the role of education in development processes. Knowledge and skills become more important in the global era of competition than ever before. Many "rate of return to education" studies have emphasized the importance of education not only in economic and social development (Matt \& Colm, 2011; Psacharopoulos, 1994) but also in personal development acquiring skills to avoid lifetime traps (Oreopounlos \& Salvanes, 2011). This is because education not only affects labour productivity and countries' ability to compete in international 


\section{DEVELOPMENT IMPACTS OF GLOBALIZATION AND . . .}

markets, but it is also necessary to attract international capital and hence affects the accumulation of capital that is essential for investment (Canton, 2007). How much knowledge and technologies can be transferred and absorbed in a country depends on the level of education and skills of the country. Thus, the capacity of the state to develop competitive industry largely depends on the level of education and skills of the population (Canton, 2007; Amsden, 1981). FDI tends to be involved in high skill activities, and creates employment opportunities for well-qualified population that ultimately raises enrolments in secondary and higher education (ODI, 2005). In fact, various researches have showed that education and skills were one of the important factors for attracting and benefiting from FDI in East Asian countries (e.g., Prime, 2012; Zhao, 2001).

Furthermore, education not only contributes to the sectors that need high-skilled human resources but also enhances the productivity of the primary sector. Scholars agree on the positive relationship between education and agricultural productivity. For example, eighteen research studies on agricultural productivity revealed that four years of primary education increased farm productivity by an average $8.6 \%$ (Lockheed et al., 1980). The same studies also found that agricultural productivity was more influenced by education in modernizing environments than in traditional environments. Similarly, a positive and significant effect of education, particularly in modernizing environments, was found in studies on education and agricultural productivity in Korea, Malaysia, Thailand and Nepal (Haddad et al., 1991). Moreover, McMahon (1999) found a strong correlation between educational enrolment and other socio-political indicators such as human rights, political stability and democratization. He also showed significant, positive correlation in primary and secondary enrolment with poverty reduction.

These literatures, however, mostly focused on a single country cases, and a few others cover all the developing countries in the world. To the authors' knowledge, there is no such cross-country analysis of the Asia-Pacific region. As the countries in the Asia-Pacific region share a broad geography yet have many examples of both successful as well as unsuccessful development experiences, comparing such experiences is useful for policymakers especially in poorer countries to understand the reasons behind their poor performance. Thus, the main purpose of this study is to reduce this research gap.

\section{METHODOLOGY}

To serve the research purpose, first we compare the trends of globalization, education and development between high-growth and low-growth countries in the Asia-Pacific region. Then, we follow an econometric approach to observe the impacts of globalization and education on economic development in the region.

\section{Comparative Approach}

In this part, we simply compare the globalization, education and development trends. Assessment of the actual situation can not only describe the validity of theoretical arguments but also provide a reliable solution to the existing debates. To compare the progress on development, we take data on GDP per capita of all the East Asia and Pacific and South Asian countries from the World Development Indicators (WDI) online database of the World Bank, and calculate the average growth rate 


\section{Crossing the Border: International Journal of Interdisciplinary Studies}

for each country from 1970 to 1990 and 1991 to 2010. Year 1990 is used to separate the two periods because the Cold War ended then and globalization process became more rapid (Sapkota, 2010). Then, we select 5 high-growth and 5 low-growth countries depending solely based on the average growth rate and the data availability of other variables for comparison. The other variables include globalization index, infant mortality, and headcount poverty. Although there are some other countries that can be considered either as high-growth or low-growth, many of them do not have sufficient data. For instance, Singapore and Afghanistan are excluded due to the unavailability of comparable data despite their very high and very low growth performance, respectively.

\section{Econometric Approach}

To complement the descriptive analysis of comparing trends as explained above, we empirically examine the impacts of globalization and education on economic development. To do so, we follow a well-established conceptual framework of economic growth models. It is found on a large body of empirical work that has been based on new growth theory, which usually employs cross-country cross-section or panel regressions using the valuable body of comparative national accounts data (For detail discussion of new growth theory, see Lucas, 1988 and Romer, 1986). Specifically, it involves cross-country regressions of GDP per capita on the input variables of output as explain by the production function together with the wide range of explanatory variables of interest. These regressions are of the form:

$$
y_{i}=\alpha+\beta X+y Z+\varepsilon
$$

where $y_{i}$ is the GDP per capita for country $i, X$ is a matrix of actors of production and other control variables. Conventionally, land, labour and capital are the main factors of production. Similarly, $Z$ is a vector (matrix) of the variable(s) of interest together, and $\varepsilon$ represents the vector of residuals.

We follow the standard practice to select the set of variables to be included in the $X$-matrix. Although most of the empirical literatures of new growth theory ignore land as a factor of production, we include land together with labour and capital as suggested by Guillo and Perez-Sebastian (2010). It uses two variables to capture the impacts of the land component of factor of production, namely; agricultural land as the percentage of total land area, and total natural resources rent as the percentage of GDP. Similarly, labour participation rate as a percentage ( $\%$ of total population ages $15+$ ), and Gross capital formation (\% of GDP) are used to control the labour and capital inputs of GDP per capita. Other control variables are mobile cellular subscriptions (per 100 people) to control for the technological penetration, and inflation, consumer prices (annual \%) to control for the efficacy of macroeconomic management.

The variables of interests are education and globalization, which are discussed in detail in previous sections. Despite having fewer observations than enrolment data, we use labour force with formal (primary, secondary and tertiary combined) education (\% of total labour force) in the empirical assessment, as many scholars claimed that enrolment is not a reliable proxy of education and skills (Stroombergen et al., 2002). Similarly, the comprehensive measure of globalization, i.e. the KOF index is used to capture the impact of overall aspect of globalization.

The data cover the annual panel from 1980 to 2010 of the 26 countries of the East Asia and the Pacific, and South Asia as per the regional groupings of countries 


\section{DEVELOPMENT IMPACTS OF GLOBALIZATION AND . . .}

by the World Bank. Appendix 2 presents the list of the selected countries. Dreher (2006) and World Bank's WDI are the data source of KOF index of globalization and remaining variables, respectively. Appendix 3 and Appendix 4 present the summary statistics of the data and the correlation matrix, respectively. The panel is not perfectly balanced due to the missing data for some countries; such as data on labour force participation rate are missing from 1980 to 1989 for the entire sample.

As we used panel data, ordinary least square (OLS) method might not be the right choice, because it cannot control the individual differences which do not change over time, such as culture, religion, geography, and so on. Thus, literature suggests two approaches, namely the fixed effect (FE) or random effect (RE) estimation models for panel data analysis. However, the Husman test indicates that the dataset is good fit to the FE over the RE model. Indeed, as explained by Kohler and Kreuter (2005, p. 245), the rationale for using the FE model is that: "The fixed-effects model controls for all time-invariant differences between the individuals, so the estimated coefficients of the fixed-effects models cannot be biased because of omitted time-invariant characteristics." Thus, such time-invariant country-fixed effects need to be controlled, which performs by the FE model. The model specification of the extended production function is as follows:

$$
\begin{aligned}
& \log (\text { GDP P P })_{i t}=\beta_{0}+\beta_{1} \log (\text { agland })_{i t}+\beta_{2} \log (\text { nrents })_{i t}+\beta_{3} \log (\text { lprate })_{i t} \\
& \quad+\beta_{4} \log (\text { gcap })_{i t^{+}} \beta_{5} \log (\text { musers }) \text { it }+\beta_{6} \log (\text { inflation })_{i t} \\
& \quad+\beta_{7} \log (\text { lfedu })_{i t}+\beta_{8} \log (\text { kofindex })_{i t}+\mu_{t}+\eta_{i}+\varepsilon_{i t}
\end{aligned}
$$

where, GDPpcp is the vector of dependent variable (i.e. GDP per capita at constant US\$2005). agland is the agricultural land as a percentage of total land area; nrents is the total natural resources rents as a percentage of total GDP; lprate is the total labour force participation rate as a percentage of total population ages 15 and above; gcap is the gross capital formation as a percentage of GDP; musers is the number of mobile cellular subscriptions per 100 people; inflation is the annual inflation rate of consumer prices as measured in percentage; lfedu is the labour force with formal (primary, secondary and tertiary combined) education as a percentage of total labour force as the measure of skills or educational advancement; and kofindex is the KOF index of globalization whose value ranges from 0 for completely not globalized or close to 100 for fully globalized or open towards the rest of the world. Similarly, $\beta$ is the coefficient of each explanatory variable that explain the magnitude and direction of impact on dependent variable; $i$ represent the group identifier, i.e. 26 countries, and $t$ represents the time identifier, i.e. 31 years from 1980 to 2010 . Finally, $\mu_{t}$ and $\eta_{i}$ denote unobserved time- and country-specific effects, respectively; and $\mu_{t}$ is the error term. All the variables are logged before running the regression to neutralize the different units of measurement. It includes time dummies in the regression, and found that time and country fixed effects are jointly significant. However, the results exclude from the result in Table 3. As "the robust variance matrix estimator is valid in the presence of any heteroskedasticiy or serial correlation" (Wooldridge, 2002, p. 275), it uses robust estimators to correct the problem of heteroskedasticiy and serial correlations.

Furthermore, as the current level of GDP per capita of a country also largely depends on the past level of GDP per capita and it grows gradually over time, it is 


\section{Crossing the Border: International Journal of Interdisciplinary Studies}

essential to include the lag dependent variable as a regressor in the right hand side of the growth equation. However, it creates several serious methodological problems as FE and OLS estimator is biased and inconsistent in short panels (Nickell, 1981). Given the dynamic nature of the regression, the common methods of dealing with country-specific effects (that is, with in-group or difference estimators) are inappropriate, even though the inclusion of period-specific dummy variables can account for the time effects. Another big problem is that most explanatory variables are likely to be jointly endogenous with economic growth, thus it is essential to control for the biases resulting from simultaneous or reverse causation. To deal with this problem, we use the generalized method of moments (GMM) estimators developed by Arellano and Bover (1995), and Blundell and Bond (1998). Based on differencing regressions or instruments to control for unobserved effects and using previous observations of explanatory and lagged-dependent variables as instruments, these estimators minimize the weak instruments problem and biases due to the endogeneity. Thus, we employ the system GMM method based on the following model that includes the lag dependent variable, i.e. $(G D P p c p)_{i t-1}$, as a regressor:

$$
\begin{aligned}
& \log (\text { GDPpcp }) i t=\beta_{0^{+}} \beta_{9} \log (\text { GDPpcp })_{i t-1}+\beta_{1} \log (\text { agland })_{i t}+\beta_{2} \log (\text { nrents })_{i t} \\
& \quad+\beta_{3} \log (\text { lprate })_{i t}+\beta_{4} \log (\text { gcap })_{i t}+\beta_{5} \log (\text { musers })_{i t}+\beta_{6} \log (\text { inflation })_{i t} \\
& \quad+\beta_{7} \log (\text { lfedu })_{i t}+\beta_{8} \log (\text { kofindex })_{i t}+\mu_{t}+\eta_{i}+\varepsilon_{i t}
\end{aligned}
$$

Several tests are performed to check the consistency of the GMM estimators, which depends on whether lagged values of the explanatory variables are valid instruments in the growth regression. Full Hansen tests of over identifying restrictions is performed to tests the validity of the full set of instruments, and Incremental Hansen test is performed to test the validity of the instruments. In both cases, null hypothesis is rejected that support the model. Similarly, Arellano and Bond (1991) test of serial correlation is performed whether the original error term (that is, $\varepsilon_{i t}$ in eq. 2 and 3 ) is serially correlated. In this case, the null hypothesis is accepted; therefore, the test supports the model.

Next two sections show the results from the comparative analysis and econometric analysis, respectively.

\section{TRENDS IN THE ASIA-PACIFIC}

Following the comparative approach, Table 1 clearly contrasts two groups of countries in the Asia-Pacific in terms of their GDP per capita growth, globalization trends and level of poverty and income inequality. High-growth rates are ranging from 3.45\% in Indonesia to 9.56\% in China during the period from 1990-2010. Although the average growth of Indonesia after 1990 is slightly over the growth rate of Bangladesh, i.e. 3.02 for the same period, the average growth of Indonesia from 1970-1990 is drastically higher than any low-growth countries. On the other hand, low-growths are ranging from $-0.35 \%$ of Papua New Guinea in 1970-1990 to 3.02\% of Bangladesh in 1991 to 2010. Although the average annual per capita GDP growth of Bangladesh in the later period shows remarkable progress, it was as low as $0.24 \%$ before 1990.

Notably, three of the high-growth countries are from East Asia, and the rest two are from South East Asia. Although there are some problems with the development 


\section{DEVELOPMENT IMPACTS OF GLOBALIZATION AND ...}

paths followed by these countries - including politically repressive governments, adverse environmental effects and poor labour conditions - many perspectives, including real improvement in human conditions as indicated by a sharp decline in infant mortality rate and reduction in poverty, their development success is impressive. Therefore, East Asian development trend is regarded as "East Asian miracle" in development discourse (World Bank, 1993).

Table 1: GDP per capita growth and other development indicators of selected countries

\begin{tabular}{|c|c|c|c|c|c|c|c|c|c|c|c|c|}
\hline \multirow[t]{2}{*}{ Country } & \multicolumn{2}{|c|}{$\begin{array}{l}\text { GDP per } \\
\text { capita growth } \\
\text { rate (\%) } \\
\end{array}$} & \multicolumn{3}{|c|}{$\begin{array}{l}\text { KOF index of } \\
\text { globalization } \\
(0-100) \#\end{array}$} & \multicolumn{3}{|c|}{$\begin{array}{l}\text { Infant mortality } \\
\text { rate (per } 1,000 \\
\text { live births) }\end{array}$} & \multicolumn{2}{|c|}{$\begin{array}{l}\text { Poverty } \\
\text { headcount } \\
\text { ratio (\%): }\end{array}$} & \multicolumn{2}{|c|}{ Gini Inde } \\
\hline & $1970-90$ & $1991-10$ & 1970 & 1990 & 2009 & 1970 & & 2010 & $1970^{\circ}$ & $2010^{4}$ & & \\
\hline \multicolumn{13}{|c|}{ High-growth countries } \\
\hline China & & & 17.2 & & 59.4 & 78 & 37 & 16 & 84 & 16 & 29 & 4 \\
\hline S. Korea & 43 & & 27.2 & & 62.4 & 41 & & 4 & - & & - & \\
\hline Malaysia & 4.21 & & 44.9 & & 77.4 & 41 & 16 & 5 & 3 & 0 & 49 & 40 \\
\hline Thailand & 5.23 & & 29.0 & 38.2 & 64.2 & 73 & 26 & 11 & 22 & 0.4 & 45 & 4 \\
\hline Indonesia & 4.82 & 3.45 & 25.5 & 35.8 & 56.3 & 100 & 56 & 27 & 63 & 18 & 30 & 3. \\
\hline \multicolumn{13}{|c|}{ Low-growth countries } \\
\hline Bangladesh & 0.24 & 3.02 & 13.3 & 21.6 & 40.7 & 160 & 103 & 38 & 61 & 43 & 26 & 3. \\
\hline Nepal & 1.01 & 2.11 & 14.9 & 23.5 & 37.4 & 163 & 97 & 41 & 78 & 25 & 30 & \\
\hline Pakistan & 2.51 & 2.03 & 28.1 & 34.8 & 52.2 & 130 & 96 & 70 & 66 & 21 & 33 & 30 \\
\hline Philippines & 1.02 & 1.71 & 28.9 & 41.6 & 56.7 & 59 & 42 & 26 & 35 & 18 & 41 & 4 \\
\hline PNG & -0.35 & 1.51 & 28.0 & 37.3 & 46.7 & 104 & 65 & 47 & - & 36 & - & \\
\hline
\end{tabular}

Notes: $\dagger$ indicates the earliest data available from 1970 to 1990; ${ }^{*}$ indicates the latest data available from 1990 and 2010; \# the KOF index ranges from 0 (fully closed) to 100 (fully opened); $\$$ Poverty headcount ratio is measured at $\$ 1.25$ a day (in purchasing power parity, PPP) (\% of population); $P N G$ = Papua New Guinea; - indicates the data is not available.

Sources: Dreher (2006), also available at: http://www.kof.ethz.ch/globalisation for KOF Index of Globalization; and World Bank's World Development Indicators available at: http://databank.worldbank.org/Data/Home.aspx for rest of the indicators (retrieved 11 July 2012).

The high-growth countries' globalization indexes are rapidly growing. For instance, while the KOF index of globalization of China, Malaysia, and Thailand was $17.2,44.9$ and 29.0 respectively in 1970; by 2009 , the index had reached 59.4, 77.4 and 64.2, respectively. South Korea and Indonesia also showed substantial progress on globalization. Interestingly, even among the high-growth countries, those with higher GDP per capita growth rates had faster increases in the globalization index in general. Such progress on economic growth also led to improved health condition of the population and thus reduced poverty. This fact can be interpreted from the data on infant mortality and poverty rates. The infant mortality rate is defined as "the number of infants dying before reaching one year of age, per 1,000 live births in a given year" and poverty rate, also called poverty headcount ratio, is "the percentage of the population living on less than $\$ 1.25$ a day at 2005 international prices" (World 


\section{Crossing the Border: International Journal of Interdisciplinary Studies}

Bank, 2011). Between 1970 and 2010, the infant mortality rate of China, Malaysia and Thailand dropped from 78, 41 and 73 to 16,5 and 11, respectively.

Furthermore, Gini index, a measure of income inequality that ranges between 0 (perfect equality) to 100 (perfect inequality), for these high-growth countries are not much worsened except for China, and even reduced for Malaysia and Thailand from 49 and 45 to 46 and 40 during the period of 1970 to 2010. However, China's Gini index worsened considerably from 29 to 43 during the same period. These results are consistent with the claim of Bruno, Ravallion and Squire (1996) who argued that growth's effects on inequality can go either way and are contingent on several other factors.

Figure 1: GDP per capita (current US\$) of selected countries, 1970-2010

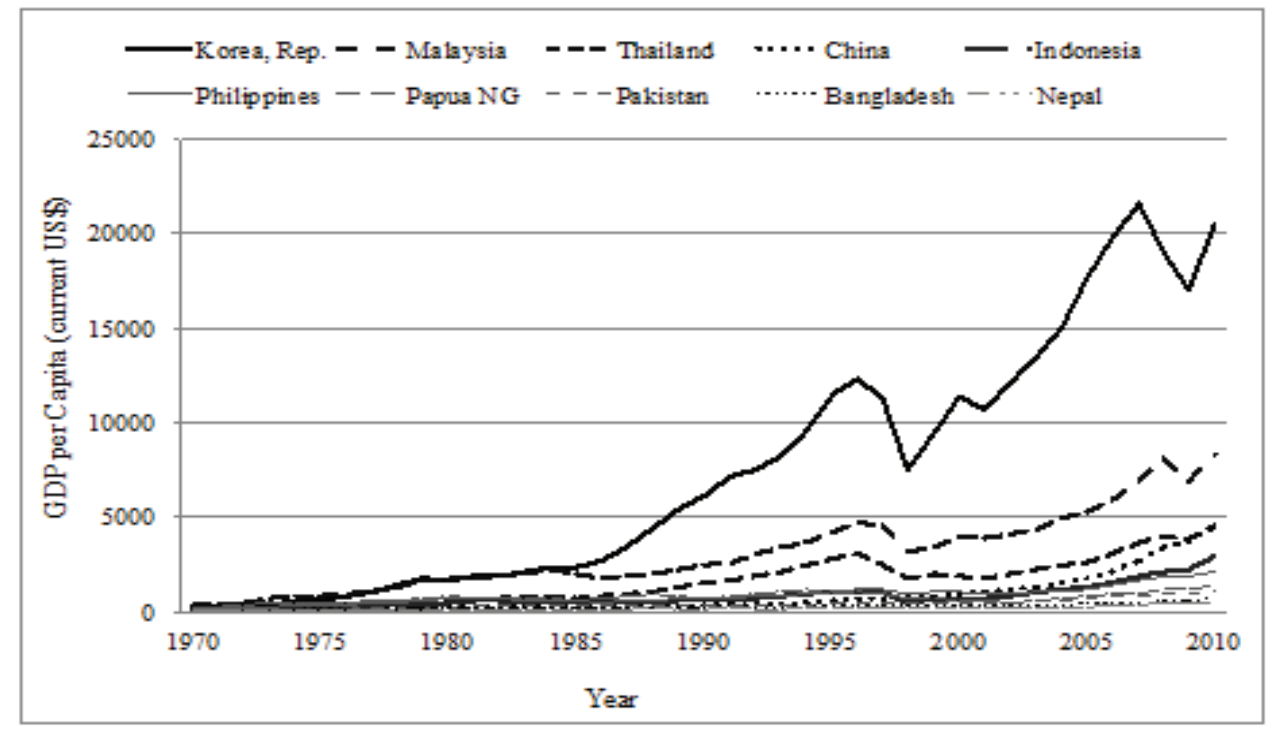

Note: Dark thick lines indicate high-growth countries; gray thin lines indicate lowgrowth countries

Source: Author's calculations based on data from the World Bank'sWorld Development Indicators available at: http://databank.worldbank.org/Data/ Home.aspx (retrieved 11 July 2012).

On the other hand, many other countries, functioning in the same global system in the Asia-Pacific, performed far worse. Despite some progress on poverty reduction, the five low-growth countries in Table 1 still have high poverty rates and infant mortality. For instance, the poverty head count rate reduced from $61 \%, 78 \%, 66 \%$, and $35 \%$ to $43 \%, 25 \%, 21 \%$, and $18 \%$ respectively for Bangladesh, Nepal, Pakistan, and the Philippines during the period of 1970 to 2010. However, the high-growth countries, China, Malaysia, Thailand, Indonesia reduced their poverty rate from $84 \%$, $3 \%, 22 \%$, and $63 \%$ to $16 \%, 0 \%, 0.4 \%$ and $18 \%$, respectively, during the same period.

Interestingly, if we compare the GDP per capita among these countries, there was not a substantial difference between the two groups at the beginning. Figure 1 shows the trend of GDP per capita at purchasing power parity (PPP) at the current price. It shows there were no substantial differences in terms of GDP per capita in 1970. Thus, 


\section{DEVELOPMENT IMPACTS OF GLOBALIZATION AND . . .}

we can observe that the high-growth countries and low-growth countries operated not only in the same global and regional environment but also nearly at the similar development level at the beginning of this study period. However, some countries achieved remarkably high GDP per capita growth over the period and the other could not. Thus, what major policies and factors impact economic growth is an interesting, yet a huge question. However, this study limits the analysis on two factors.

First, globalization can be considered one of the major factors that impact such a different growth path of the countries in the region. The clear indication of this is the globalization trends of the high-growth and low-growth countries, which are similar with their growth trends as shown in Figure 2. Interestingly, globalization level was lower in some of the high-growth countries than that of low-growth countries at the beginning. However, high-growth countries globalized quickly and reached far higher level than that of the low-growth countries. For instance, Malaysia had significantly higher level of globalization already in 1970 but other high-growth countries had no substantial differences with low-growth countries. However, highgrowth countries' level of globalization grew faster together with their development, and in 2009, they all reached much higher level than low-growth countries except for the Philippines. Notably, like in GDP per capita, progress in globalization is recorded extremely fast for South Korea.

Figure 2: Globalization trend (KOF index of globalization), 1970-2009

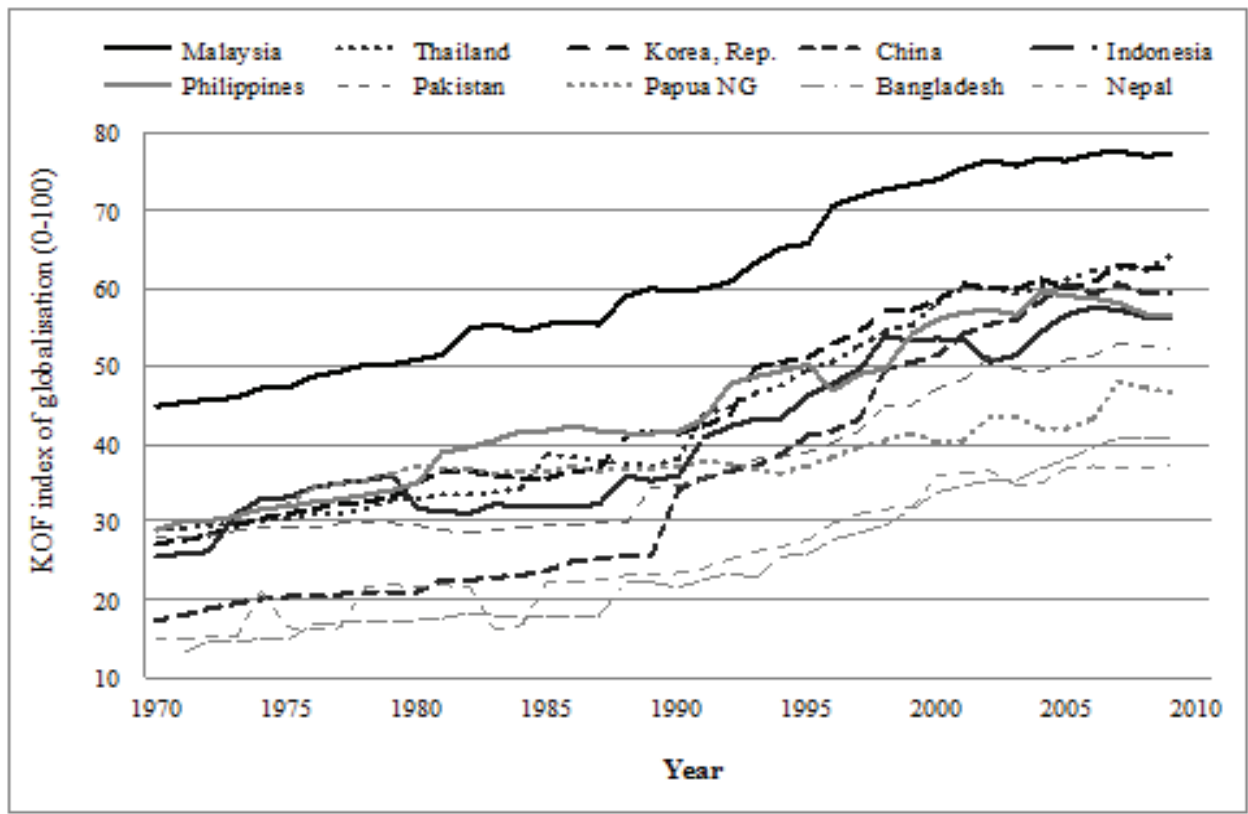

Note: Dark lines for high-growth and grey lines for low-growth countries

Source: Author's calculations based on data from Dreher (2006), http://globalization. kof.ethz.ch/query/ (retrieved: 14 July 2012)

Some scholars blame globalization for the increased income inequality within and among countries over the past decade, because the gap in average incomes between the world's richest and poorest countries has increased (Wolf, 2004). 


\section{Crossing the Border: International Journal of Interdisciplinary Studies}

However, the Gini index in Table 1 reveals no significant differences between high-growth countries and low-growth countries in the Asia-Pacific. For example, the Gini index for high-growth countries ranges from 42.45 in Thailand to 31.59 in South Korea, whereas, for the low-growth countries, it ranges from 31.02 for Bangladesh to 50.88 for Papua New Guinea. It appears that rapid economic growth and globalization do not necessarily worsen the income inequality within a country.

Second, initial level of education of a country can be considered another contributing factor for economic growth. Table 2 shows the human resource level, represented by gross enrolment ratio (GER) and percentage of labour force with any level of formal education of the selected high-growth and low-growth countries. GER is widely available, and defined as "total enrolment in a specific level of education, regardless of age, expressed as a percentage of the eligible official school-age population corresponding to the same level of education in a given school year" (UNESCO, 2009, p. 9).

Data on labour force by level of education are available for fewer countries and also for limited years, hence the GER is discussed more here. While comparing development data in Table 1 and education data in Table 2, high-growth countries have higher enrolment rates and higher percentages of educated labour force than low-growth countries. For instance, the primary enrolment rate in China was 121.9 and 111.3 in 1976 and 2010, respectively, whereas, secondary enrolment rate was 39.4 in 1970 and 75.5 in 2010. China's GER is remarkably high from the beginning of the study period. Therefore, it is argued that China had a substantial investment in human resources that critically contributed to its economic development. The other countries in this group also have a strong human resource base.

On the other hand, all the low-growth countries had very low levels of human resources, especially at the beginning. For instance, Nepal's primary enrolment rate in 1970 was 24.5 , whereas secondary enrolment was 8.7. Rest of the countries in this group, except the Philippines; also have quite low level of educated labour force.

Remarkably, gender gap in enrolment in both primary and secondary level is very high in most of the low-growth than compare to high-growth countries. In 1970, the secondary school enrolments of boys were more than three times for Nepal, Pakistan and Papua New Guinea, and nearly three times for Bangladesh. Such gaps in primary levels were also mostly two times higher for boys than girls except for the Philippines. These gaps were reduced significantly over time, however, not as much as the high-growth countries. Interestingly, as the best growth performer among the selected low-growth countries, Bangladesh achieved the gender parity with several percentage more girls' enrolments in both the primary and secondary level in 2010. This result is consistent with the findings of Busse and Spielmann (2006) that gender inequality in terms of labour-market participation and education is negatively related with labour-intensive exports that ultimately hurt growth. Indeed, the growth performance of Bangladesh in recent decades is driven by labour-intensive exports ( $\mathrm{Al}$ Mamun \& Nath, 2005).

Adult literacy rate is another widely used educational indicator that captures the overall level of educational development of a developing country. As Sen (1999) 


\section{DEVELOPMENT IMPACTS OF GLOBALIZATION AND . . .}

found strong correlations between literacies and other determinants of wellbeing such as income, health and women's labour force participation, importance of literacy in human development is reflected by the central position of adult literacy rate in the Human Development Index of the United Nations (Basu, Maddox \& Robinson-Pant, 2008). Sen (1999, p. 103) further argued that illiteracy is a 'focal feature' of capability deprivation and social injustice. Consequently, adult literacy is used widely in development research and practice, and there are high concerns and commitments to increase the literacy level in the light of Education for All (EFA) targets. As defined by UNESCO $(2009$, p. 3), "adult literacy rate is the percentage of people ages 15 and above who can, with understanding, read and write a short, simple statement on their everyday life."

Table 2: School enrolment in selected countries

\begin{tabular}{|c|c|c|c|c|c|c|c|c|c|c|c|c|c|c|c|c|c|c|}
\hline \multirow{3}{*}{ Country } & \multicolumn{6}{|c|}{ Primary eurolment (96) } & \multicolumn{6}{|c|}{ Secondary enrolment (96) } & \multicolumn{6}{|c|}{ Labour force with formal education $(9 \%)$} \\
\hline & \multicolumn{3}{|c|}{1970} & \multicolumn{3}{|c|}{2010} & \multicolumn{3}{|c|}{1970} & \multicolumn{3}{|c|}{2010} & \multicolumn{3}{|c|}{1990} & \multicolumn{3}{|c|}{2008} \\
\hline & Total & Female & Male & Total & Fenale & Male & Total & Female & Male & Total F & Female & Male & Total $\mid \mathrm{F}$ & Female & Male & Total & Female & Male \\
\hline \multicolumn{19}{|c|}{ High-growth covvtries } \\
\hline China $^{*}$ & 111.2 & 113.3 & 109.5 & 111.2 & 111.2 & 111.5 & 39.4 & 32.1 & 46.3 & 81.1 & 82.8 & 79.7 & \multicolumn{3}{|c|}{-} & \multicolumn{3}{|c|}{ - } \\
\hline S. Korea 4 & 103.4 & 102.9 & 103.9 & 104.2 & 103.6 & 104.7 & 41.6 & 32.5 & 50.2 & 97 & 96.4 & 97.6 & 99.9 & 100.0 & 100 & 100 & 100 & 100 \\
\hline Malaysia 444 & 88.7 & 83.4 & 93.9 & 96.2 & 96.1 & 96.3 & 34.2 & 27.9 & 40.7 & 68.3 & 70.7 & 65.9 & \multicolumn{3}{|c|}{-} & 95.5 & 94.5 & 96.2 \\
\hline Thailand4*4\% & 79.5 & 75.4 & 83.5 & 90.6 & 90.1 & 91.2 & 17.4 & 14.6 & 20.2 & 77.2 & 80.3 & 74.2 & \multicolumn{3}{|c|}{ - } & \multicolumn{3}{|c|}{ - } \\
\hline Indonasia & 79.2 & 73.5 & 84.8 & 118.1 & 119.1 & 117.1 & 16.9 & 11.8 & 21.9 & 77.1 & 77.2 & 77 & 71.9 & 66.8 & 78.3 & 82.9 & 79.2 & 85.1 \\
\hline \multicolumn{19}{|c|}{ Low-growth couvtries } \\
\hline Bangladesh \# & 51.2 & 33.9 & 67.5 & 103.3 & 106.1 & 100.5 & 15.5 & 8.5 & 21.9 & 49.2 & 51.5 & 47.1 & \multicolumn{3}{|c|}{-} & \multicolumn{3}{|c|}{-} \\
\hline Nepal $=$ & 24.5 & 7.5 & 40.4 & 115.1 & 106.2 & 123.4 & 8.7 & 2.6 & 14.5 & 43.5 & 40.7 & 46 & 39.7 & 24.4 & 56.6 & 53.3 & 41.8 & 67.4 \\
\hline Pakistan $=$ & 43.1 & 23.4 & 61.5 & 94.9 & 85.2 & 104.2 & 15.2 & 6.3 & 23.4 & 34.2 & 29.3 & 38.8 & \multicolumn{3}{|c|}{-} & 52.3 & 23.5 & 59.6 \\
\hline philippines $=\#$ & 113.8 & \multicolumn{2}{|c|}{-} & 105.8 & 104.6 & 106.9 & 48.5 & 47.2 & 49.8 & 84.8 & 88.2 & 81.5 & \multicolumn{3}{|c|}{-} & 98.3 & 98.3 & 98.3 \\
\hline PNG $=$ & 47 & 34.8 & 58.8 & 60 & 56.5 & 63.4 & 6.9 & 3.7 & 10.1 & \multicolumn{3}{|c|}{ - } & \multicolumn{3}{|c|}{-} & \multicolumn{3}{|c|}{-} \\
\hline
\end{tabular}

Notes: ${ }^{*}=$ China's primary enrolment is for $1976 ;{ }^{*}=$ South Korea's primary enrolment and labour force with formal education are for 1971; ${ }^{* * *}=$ Malaysia's primary is for 2005 and secondary enrolment is for 2009; ${ }^{* * *}=$ Thailand's primary enrolment is for 1971 and 2009; \# = Bangladesh's secondary enrolment is for 1972; both the primary and secondary enrolment is for 2009 instead of 2010; \#\# = Nepal's primary enrolment is for 2002 and secondary enrolment is for 2006, initial labor force with formal education in for 1995; \#\#\#= Pakistan's primary enrolment is for 1971; \#\#\# = Papua New Guinea's primary enrolment is for 1970 and 2008; --- =data not available; $P N G=P a p u a$ New Guinea

Sources: World Bank's World Development Indicators available at: http://databank. worldbank.org/Data/ Home.aspx (retrieved 11 July 2012) 


\section{Crossing the Border: International Journal of Interdisciplinary Studies}

Figure 3 presents the overall adult literacy rates for both high-growth and lowgrowth countries in 1980-1982 and 2005-2008. The figure excludes South Korea and Papua New Guinea due to the lack of data. The data reveal that high-growth countries already had adult literacy rates above $65 \%$ in 1980-1982. Interestingly, these highgrowth countries did not have big gaps between them, whereas the low-growth countries' literacy rates varied widely from country to country. Notably, three South Asian countries had adult literacy rates lower than $30 \%$ in 1980-1982. From the first to the second period, high-growth countries achieved progress and reached higher than $90 \%$ in 2005-2008, but low-growth countries could not even reach 60\% except the Philippines. These data also supports the crucial importance of sound educational base for economic development. The Philippines is an exception in this case too as the literacy rate of the country was unusually high among the low-growth countries and compared favourably with the rates in the high-growth countries in both periods.

Figure 3: Comparison of total adult literacy rates (1980-1982 and 2005-2009)

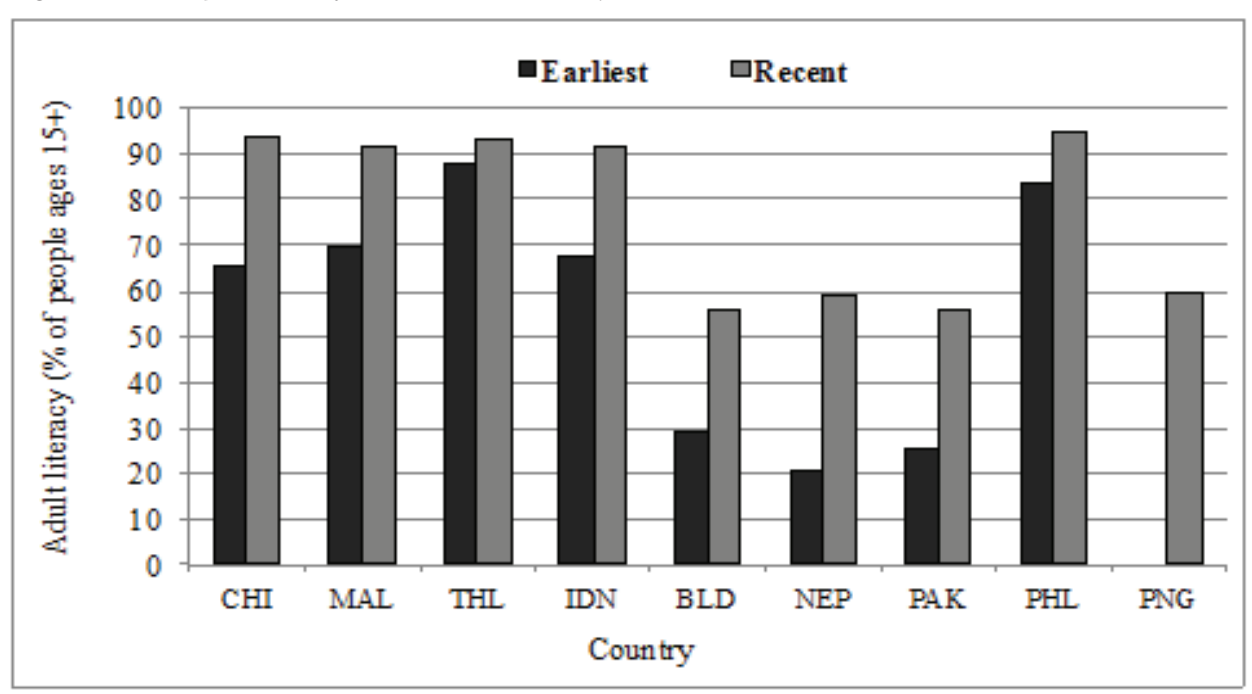

Notes: The earliest period is between 1980 and 1982 and the recent period is between 2005 and 2009 depending on countries and their data availability; the data are presented in Appendix 1; $C H N=C h i n a ; M A L=$ Malaysia; $T H L=$ Thailand; $I N D=I n d o n e s i a ;$ $B L D=$ Bangladesh; $N E P=$ Nepal; $P A K=$ Pakistan; and $P H L=$ the Philippines

Source: Author's calculations based on data from the World Bank's World Development Indicators available at: http://databank.worldbank.org/Data/ Home.aspx (retrieved 11 July 2012)

Figure 4 presents male and female adult literacy rates for both the earliest years and the recent years. Gender gap in adult literacy is also less pronounced in highgrowth countries than in low-growth countries. Among the four high-growth countries, China had the lowest women literacy in the earliest period. However, the country achieved a tremendous progress, reached almost $90 \%$ in recent years, and caught up with other countries in the same category. On the other hand, Nepal had the lowest literacy rate for both males and females during the earliest period. Its female adult literacy rate was less than $10 \%$, whereas the male literacy rate was almost $40 \%$. The other two low-growth countries (from South Asia), Bangladesh and Pakistan, 


\section{DEVELOPMENT IMPACTS OF GLOBALIZATION AND . . .}

also had extremely low level of female adult literacy, at less than $20 \%$. The gender gap in adult literacy was as high as about $20 \%$, because the rate for males was about $40 \%$. Male adult literacy rates for low-growth countries in recent years ranged from $40 \%$ to $70 \%$, but female adult literacy ranged from $40 \%$ to $50 \%$. These comparisons revealed that gender equity in education is also crucial for economic development. Again, the Philippines is an exception as the country had lower level of the gender gap in both periods despite having extremely low GDP per capita growth rate over the period.

Figure 4: Gender-wise comparison of adult literacy rates (1980-1982 and 2005-2009)

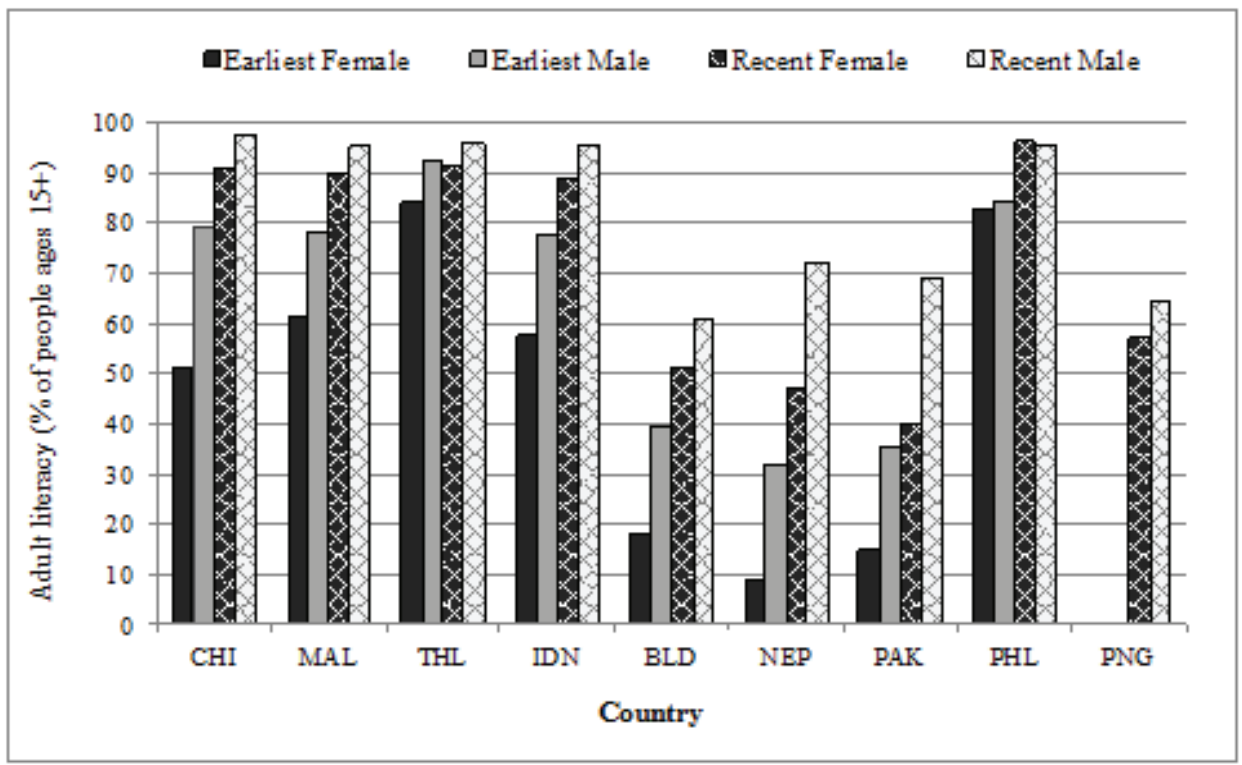

Notes: The earliest period is between 1980 and 1982 and the recent period is between 2005 and 2009 depending on countries and their data availability; the data are presented in Appendix 1; CHN=China; $M A L=$ Malaysia; THL=Thailand; IND=Indonesia; $B L D=$ Bangladesh; $N E P=N e p a l ; P A K=$ Pakistan; and $P H L=$ the Philippines

Source: Author's calculations based on data from the World Bank's World Development Indicators available at: http://databank.worldbank.org/Data/ Home.aspx (retrieved 11 July 2012)

Simple comparison of the trends in GDP per capita growth rates, levels of globalization and some education indicators reveal that high-growth countries have sound educational base and higher level of globalization over the period than that of the low-growth countries except than the Philippines. The high economic growth has also supported by many other good policies and institutions. As noted by Stieglitz (1994, p. 172-173), the major policy components are maintaining macroeconomic and political stability, adaptability of government policy as per the need of changing market and society, active government role in creating market institutions, promoting accumulation of physical and human capital, altering the allocation of resources to stimulate growth, and government policies supporting investment through incentive, risk-sharing and intervening international economic relations for technology transfer and enhance national interests. Of course, these generalizations, especially made for East Asian high-growth countries, are not equally application for all the 


\section{Crossing the Border: International Journal of Interdisciplinary Studies}

high-growth countries, yet these policies are the key ingredients of policy instruments of the high-growth countries in the Asia-Pacific.

The importance of good policies for high growth performance is also reflected in the case of the Philippines as the country was unable to attain high-growth despite having high level of educational and globalization indicators. The Philippines suffered from the political instability since decades, and the political and economic power largely controlled by the landlords and business elites that hardly develop sound policy environment in the country (Skinner, 2007). High level of corruption is another most cited reason behind the low growth performance, as the Philippines remained one of the most corrupt countries in recent decades (Batala, 2000). The Philippines case can be an interesting exploration. It is beyond the scope of this article though.

\section{IMPACTS AND DISCUSSION}

This section presents the empirical results on the impacts of globalization and education on economic growth. Table 3 shows the regression results of both the FE and GMM methods. While more variables are found to be significant from GMM (in Column [2]) compared to the FE method (in Column [1]), the level of significance is also increased for some variables in GMM. For instance, positive impact of labour participation rate and mobile cellular subscriptions on GDP per capita are significant at $10 \%$ and $5 \%$ respectively, and negative impact of inflation is significant at $5 \%$ in GMM method, however, these variables are insignificant in FE model. Similarly, total natural resource rents and labour force with formal (primary, secondary and tertiary combined) education are found to be more significant from GMM method that in FE method. While agricultural land is found insignificant in both the model, the level of significance of the impacts of gross capital formation and the KOF index of globalization on GDP per capita are remained same at $1 \%$ in both the model. Overall, the results are firmly consistent and the models are reliable. Although the theoretical linkages between globalization and development, and education and development are discussed at length in previous sections, some precise rationales of the empirical results are briefly discussed in the following paragraphs. As GMM reduces the biases caused by endogeneity and reverse causality, the discussion based on the results from GMM method.

Strong positive and significant coefficient of the lag dependent variable in GMM model indicates that any country's present GDP per capita is highly depends on its past level. This also implies that FE model is weak to explain the relationship between dependent and independent variables, as the model does not include lag dependent variable.

As expected, education indicator, i.e. proxied by the labour force with formal education, is found to have highly significant positive impact on GDP per capita. This result is in line with the findings of the cross-country growth regressions by Barro (1991, 2001) and Hanushek and Woessmann (2008), who found highly significant positive impacts of all levels of school (primary, secondary and tertiary) attainments on per capita income growth. Theoretically, education promotes growth through increased labour productivity, innovation, competitive advantages in global market, and international capital (Canton, 2007). This fact is further evident by the poor significance of the impact of labour force participation rate on GDP per capita. Thus, uneducated or poorly educated labour force cannot affect much on income growth, but does it more systematically by more educated ones. 
DEVELOPMENT IMPACTS OF GLOBALIZATION AND . . .

Table 3: GDP per capita, globalization, and education, 1980-2010

$<$ Dependent variable: Logarithm of GDP per capita $>$

\begin{tabular}{|c|c|c|}
\hline Explanatory variables & [1] FE & [2] GMM \\
\hline Lag dependent variable $\left(\ln G D P_{p} c p_{a-1}\right)$ & - & $.700^{* 8 *}(0.085)$ \\
\hline Agricultural land ( $\%$ of land area) & $-.142(0.145)$ & $-.040(0.035)$ \\
\hline $\begin{array}{l}\text { Total natural resources rents ( } \% \text { of GDP) } \\
\text { Labour participation rate, total ( } \% \text { of total } \\
\text { population ages } 15+)\end{array}$ & $\begin{array}{c}-.05 *(0.027) \\
.779(0.59)\end{array}$ & $\begin{array}{c}-.036^{* * *}(0.011) \\
.512^{*}(0.192)\end{array}$ \\
\hline Gross capital formation ( $\%$ of GDP) & $.32^{* * *}(0.095)$ & $.191^{* * *}(0.023)$ \\
\hline $\begin{array}{l}\text { Mobile cellular subscriptions (per } 100 \text { people) } \\
\text { Inflation, consumer prices (annual } \% \text { ) } \\
\text { Labour force with all level of education ( } \% \text { of total) } \\
\text { KOF index of globalization ( } 0-100) \\
\text { Constant }\end{array}$ & $\begin{array}{l}.008(0.008) \\
-.017(0.012) \\
.13^{* *}(0.066) \\
.973^{* * *}(0.222) \\
1.133(2.625)\end{array}$ & $\begin{array}{r}.007^{* *}(0.003) \\
-.013^{* *}(0.005) \\
.082^{* * *}(0.027) \\
.101^{* * *}(0.033) \\
-.728(0.747)\end{array}$ \\
\hline R-Square (within) (FE) & .7421 & \\
\hline F-Statistics & $20.50^{* * *}$ & \\
\hline Wald $x^{2}$ & & $15334.31 * * *$ \\
\hline Number of observations & 74 & 53 \\
\hline Number of countries & 26 & 26 \\
\hline
\end{tabular}

Notes: Fixed effect (FE) estimations are reported; ${ }^{*},{ }^{* *},{ }^{* *}$ indicate that the coefficient is significant at the 90, 95 and 99 percent level respectively; ( ) shows robust standard errors adjusted for clusters in countries; time dummies were included in the regression; and the time and country fixed effects are jointly significant; all variables are logged to normalize the different units of the variables; annual data from 1980 to 2010 of 26 countries in East Asia and the Pacific and South Asia are used; the names of the countries and summary statistics of the data are given in Appendix 2 and Appendix 3, respectively.

Sources: The data of KOF index of globalization are taken from Dreher (2006) and remaining variables are taken from the World Bank's WDI online database.

Similarly, the positive impact of KOF index of globalization on GDP per capita is also found significant at $1 \%$. This result supports the numerous previous findings of a positive association of globalization and economic growth, such as Wolf (2004), Dreher (2006), and Green et al (2007). As Sachs and Warner (1995) and many other argued that growth impacts of globalization comes through competitiveness and economic efficiency, greater specialization and learning economies, and FDI and technological upgrading, among others.

The conventional factors of production, land and capital, demonstrate different results. While the result shows highly significant (at 1\%) positive impacts of gross capital formation on GDP per capita, agricultural land is found insignificant. In fact, land component is being weaker over time due to rapid industrialization and continuous technological innovation that demands more skilled labour and more capital investment than land. Growth impacts of capital are well established in economic literature (for detail, see Bond, Leblebicioglu \& Schiantarelli, 2010). Unlike labour and capital, land is rather a constant factor of production. This might be the reason why current growth literatures widely ignore the land component in their production function. However, another land related variable, the total natural resource rents is found to have significant negative impact on GDP per capita. Resource rent is the difference between the price at global market and its respective extraction or production costs, and total natural resource rents are the sum 


\section{Crossing the Border: International Journal of Interdisciplinary Studies}

of oil rents, natural gas rents, coal rents (hard and soft), mineral rents, and forest rents (World Bank, 2012). The negative relationship between natural resource exports and economic growth is also found by Torvik (2009) even after controlling many other factors. However, it does not mean that resource exports leads to lower growth, rather better policy and institutions matters more, which can be advanced through quality education and globalization (for detail, see Trovik, 2009).

Other control variables, mobile cellular subscriptions as the proxy of technological penetration and inflation as the proxy for macroeconomic management also found to be significant (at 10\% level) to affect on GDP per capita. However, the effect of mobile cellular subscription is positive and the inflation is negative. These findings are also in line with the existing literatures, such as Shridhar and Shridhar (2007), who empirically showed the positive impacts of mobile technology on economic growth in developing countries. Similarly, using cross country panel data of both industrialized and developing countries in dynamic GMM model, Lopez-Villavicencio and Mignon (2011) found strong negative impact of inflation on economic growth, although they found growth enhancing effects of inflation up to a certain level in developed countries.

Overall, the results from the data of Asia-Pacific countries reconfirm the key role of education and globalization on GDP per capita growth.

\section{CONCLUSION}

This study compared the trends between five high-growth and five low-growth countries and performed an econometric analysis of 26 countries from the Asia-Pacific region. The results show that education and globalization have significant impact on economic development. Although globalization is claimed to be positive for national development, lack of educated human resources limits countries' ability to take advantage of the positive benefits of the globalization process. The importance of having educated human resources in development is multifaceted. On the one hand, education contributes to growth directly through enhanced labour productivity, technological development together with building social trust and cohesion. On the other hand, education promotes growth indirectly by lubricating globalization process through attracting international capital and know-how, advancing competitiveness in global market, and building efficient institutions. This can be seen from the experience of high-growth countries, as they had well educated human resources, to compete in the global market and benefited significantly from the process of globalization.

Although, this study shows that education is a crucial factor in obtaining significant development gains from globalization, the Philippines appears to be an exception. It clearly indicates that globalization and sound educational base is required but not sufficient condition for development. It should be supported by good policies and institutions, which critically lack in the Philippines. Although some of the effective policies are identified for high-growth countries in the Asia-Pacific, which is not fully applicable in a particular country with unique geopolitical, sociocultural, and economic characteristics. Exploration of the Philippines case, therefore, deserves an in depth analysis, which can recommend effective policies for development of the country.

\section{ACKNOWLEDGEMENTS}

The preliminary version of this article was presented at the 44th Annual Conference of the Asian Studies on the Pacific Coast (ASPAC) hosted by the Portland State Uni- 


\section{DEVELOPMENT IMPACTS OF GLOBALIZATION AND . . .}

versity, USA, in June 2010 and published as a Working Paper of the Global Institute for Asian Regional Integration. We wish to thank Tsuneo Akaha, Kuroda Kazuo and Iida Takeshi for their feedback and suggestions. We also thank to anonymous referees for their very useful comments.

\section{NOTES}

1. According to the WDI online database, total natural resources rents are the sum of oil rents, natural gas rents, coal rents (hard and soft), mineral rents, and forest rents. The natural resource rents is the total revenue that can be generated from the extraction of the natural resource, less the cost of extracting the resource.

\section{REFERENCES}

Al Mamun, K. A. \& Nath, H. K. (2005). Export-led growth in Bangladesh: A time series analysis. Applied Economics Letters, 12(6), 361-364.

Amsden, A. H. (1989). Asia's next giant: South Korea and late industrialization. New York: Oxford University Press.

Arnal, E \& Hijzen, A. (2008). The impact of foreign direct investment on wages and working conditions, OECD Social, Employment and Migration Working Papers No. 68, Paris.

Arellano, M. \& Bond, S. (1991). Some tests of specification for panel data: Monte Carlo evidence and an application to employment equations. The Review of Economic Studies, 58(2), 227-297.

Arellano, M. \& Bover, O. (1995). Another look at the instrumental variable estimation of error components models. Journal of Econometrics, 68(1), 29-51.

Barro, R. (1991). Economic growth in a cross section of countries. Quarterly Journal of Economics, 106, 407-443.

Barro, R. (2001). Human capital and growth. American Economic Review, 91, 12-17.

Basu, K., Maddox, B. \& Robinson-Pant, A. (2008). Literacies, identities and social change: Interdisciplinary approaches to literacy and development. Journal of Development Studies, 44(6), 769-778.

Batala, E. (2000). De-institutionalizing corruption in the Philippines: Identifying strategic requirements for reinventing institutions, paper presented at the "Institutionalizing Strategies to Combat Corruption: Lessons from East Asia" conference sponsored by the KAS and the DLSU-YCEA, Manila, August 12-13, 2000. Retrieved from http:// unpan1.un.org/intradoc/groups/public/documents/apcity/unpan013117.pdf

Blundell, R. \& Bond, S. (1998). Initial conditions and moment restrictions in dynamic panel data models. Journal of Econometrics, 87(1), 115-143.

Bond, S., Leblebicioglu, A. \& Schiantarelli, F. (2010). Capital accumulation and growth: A new look at the empirical evidence. Journal of Applied Econometrics, 25(7), 1073-1099.

Bruno, M., Ravallion, M. \& Squire, L. (1996). Equity and growth in developing countries: old and new perspectives on the policy issues. The World Bank, Policy Research Working Paper Series 1563.

Canton, E. (2007). Social returns to education: Macro: evidence. De Economist. 155(4), 449-468.

Crenshaw, E. M. and A. Z. Ameen \& Christenson, M. (1997). Population dynamics and economic development: Age-specific population growth rates and economic growth in developing countries, 1965 to 1990. American Sociological Review, 62(6), 974-984.

Dreher, A. (2006). Does globalization affect growth? Empirical evidence from a new index. Applied Economics, 38(10), 1091-1110.

Green, A., A.W. Little, S.G. Kamat, M. Oketch \& Vickers, E. (2007). Education and de- 


\section{Crossing the Border: International Journal of Interdisciplinary Studies}

velopment in a global era: Strategies for 'successful' globalisation. Educational Paper No. 69, Retrieved from http://www.dfid.gov.uk/r4d/PDF/Outputs/PolicyStrategy/ ResearchingtheIssuesNo69.pdf

Guillo, M. D. \& Perez-Sebastian, F. (2010). Reexamining the Role of Land in Economic Growth. Retrieved from http://merlin.fae.ua.es/fidel/papers/Reexam7.pdf

Gwartney, James D. \& Robert R. L. (2002). Economic Freedom of the World: Annual Reports. Retrieved from http://www.freetheworld.com/efw_previous.html.

Haddad, W. D., M. Carnoy, R. Rinaldi \& Regel, O. (1990). Education and development: Evidence for new priorities. Retrieved from http://www.eric.ed.gov/PDFS/ED326471.pdf.

Hanushek, E. \& Woessmann, L. (2008). The role of cognitive skills in economic development. Journal of Economic Literature, 46, 607-668.

Lockheed, M. E., D. T. Jamison, \& Lau, L. J. (1980). Farmer education and farm efficiency: A survey. In T. King (Ed.), Education and Income (pp. 37-76). World Bank Staff Paper 402, Washington D. C.: World Bank.

Lopez-Villavicencio, A. \& Mignon, V. (2011). On the impact of inflation on output growth: Does the level of inflation matter? Journal of Macroeconomics, 33(3), 455-464.

Lucas, R. (1988). On the mechanics of economic development. Journal of Monetary Economics, 22, 3-42.

Matt, D. \& Colm, H. (2011). Economic returns to education: What we know, what we don't know, and where we are going-some brief pointers. Economics of Education Review, 30(6), 1118-1122.

McMahon, W. (1999). Education and development, Oxford: Oxford University Press.

Nickell, S. J. (1981). Biases in dynamic models with fixed effects. Econometrica, 49, 1417-1426.

ODI (Overseas Development Institute). (2005). Globalisation and education, ODI Briefing Paper. Retrieved from http://www.odi.org.uk/resources/download/1947.pdf.

Oreopoulos, P. \& Salvanes, K. G. (2011). Priceless: The no pecuniary benefits of schooling. Journal of Economic Perspectives, 25(1), 159-184.

Prime, P. B. (2012). Utilizing FDI to stay ahead: The case of singapore. Studies in Comparative International Development (SCID), 47(2), 139-160.

Psacharopoulos, G. (1994). Returns to investment in education: A global update. World Development, 22 (9), 1325-1343.

Romer, P. (1986). Increasing returns and long-run growth. Journal of Political Economy, 94, 1002-1037.

Sachs, J. \& Warner, A. (1995). Economic reform and the process of global integration. Brookings Papers on Economic Activity, 1, 1-118.

Sapkota, J. B. (2010). Globalisation's convergence effect on human quality of life (QOL) in Asia: Evidence from the KOF index of globalisation. Asian Regional Integration Review, 2(1), 28.

Sapkota, J. B. (2011). Mainstreaming globalisation in poverty reduction strategy papers in the Asia-Pacific region. Development in Practice, 21(7), 999-1012.

Sen, A.K. (1999). Development as freedom. Oxford: Oxford University Press.

Sridhar, K. S., \& Sridhar, V. (2007). Telecommunications infrastructure and economic growth: Evidence from developing countries. Applied Econometrics and International Development, 7(2). Retrieved from http://ssrn.com/abstract=1250082.

Stiglitz, J. E. (1996). Some lessons from the East Asian miracle. World Bank Research Observer, 11 (2), 151-177.

Stroombergen, A., Rose, D. \& Nana, G. (2002). Review of the statistical measurement of human capital, research report, Statistics New Zealand, Auckland. Retrieved from http:// unpan1.un.org/intradoc/groups/public/ documents/apcity/unpan016774.pdf 


\section{DEVELOPMENT IMPACTS OF GLOBALIZATION AND ...}

Torvik, R. (2009). Why do some resource abundant countries succeed while others do not? Oxford Review of Economic Policy, 25(2), 241-256.

UNESCO (United Nations Educational, Scientific and Cultural Organization), Institute for Statistics. (2009). Educational indicators: Technical guidelines. Retrieved from http://www.uis.unesco.org/Library/Documents/eiguide09-en.pdf.

Urata, S. \& Yokota, K. (1994). Trade liberalization and productivity growth in Thailand. The Developing Economies, 32(4), 444-459.

Wolf, M. (2004). Why globalisation works? Boston: Yale University Press.

World Bank. (1993). The East Asian miracle: Economic growth and public policy. Washington, D.C.: World Bank.

World Bank. (2012). World Development Indicators, online database of the World Bank, available at: http://databank.worldbank.org/ddp/home.do.

Zhao, Z. (2001). Foreign direct investment and relative wages: The case of China. China Economic Review. 12(1), 40-57.

\section{APPENDICES}

Appendix 1: Comparison of Adult Literacy Rates of Selected Countries

\begin{tabular}{|c|c|c|c|c|c|c|}
\hline \multirow{2}{*}{ Country } & \multicolumn{3}{|l|}{ Earliest } & \multicolumn{3}{|l|}{ Recent } \\
\hline & Female & Male & Total & Female & Male & Total \\
\hline \multicolumn{7}{|l|}{ High-growth countries } \\
\hline China & 51.14 & 79.19 & 65.51 & 90.94 & 96.89 & 93.98 \\
\hline S. Korea & -- & -- & -- & $\cdots$ & -- & -- \\
\hline Malaysia & 61.25 & 78.15 & 69.52 & 90.29 & 94.58 & 92.46 \\
\hline Thailand & 83.89 & 92.21 & 87.98 & 91.53 & 95.60 & 93.51 \\
\hline Indonesia & 57.69 & 77.47 & 67.31 & 89.1 & 95.38 & 92.19 \\
\hline \multicolumn{7}{|l|}{ Low-growth countries } \\
\hline Bangladesh & 17.97 & 39.73 & 29.23 & 51.02 & 60.7 & 55.9 \\
\hline Nepal & 9.15 & 31.67 & 20.57 & 46.89 & 72.05 & 59.14 \\
\hline Pakistan & 14.77 & 35.38 & 25.73 & 40.08 & 68.87 & 55.53 \\
\hline Philippines & 82.76 & 83.89 & 83.32 & 95.83 & 95.01 & 95.42 \\
\hline Papua New Guinea & $\ldots$ & $\cdots$ & $\cdots$ & 56.52 & 63.64 & 60.10 \\
\hline
\end{tabular}

Notes: Earliest data are from 1982 to 1984 and the most recent data are from 2005 to 2009; '---' means data is not available.

Source: The World Bank's World Development Indicators (WDI) online database.

\section{Appendix 2: List of Countries Included on Regression Analysis}
1. Australia
4. China
7. India
10.South Korea
13. Magnolia
16. Pakistan
19.Samoa
22.Sri Lanka
25. Vanuatu

2. Bangladesh

3. Bhutan

5. Fiji

8. Indonesia

6. Hong Kong

11. Lao PDR

9. Japan

14. Nepal

12. Malaysia

17. Papua New Guinea

20. Singapore

15. New Zealand

23. Thailand

26. Vietnam

18. Philippines

21. Solomon Island

24. Tonga 


\section{Crossing the Border: International Journal of Interdisciplinary Studies}

Appendix 3: Summary Statistics

\begin{tabular}{|c|c|c|c|c|c|}
\hline Variable & Observation & Mean & Std. Dev. & Minimum & Maximum \\
\hline $\begin{array}{l}\text { GDP per capita, PPP (constant } \\
2005 \text { int'1 \$) }\end{array}$ & 794 & 7870.93 & 10324 & 523.95 & 51966.4 \\
\hline $\begin{array}{l}\text { Agricultural land (\% of land } \\
\text { area) }\end{array}$ & 774 & 32.09 & 21.75 & 0.00 & 83.98 \\
\hline $\begin{array}{l}\text { Total natural resources rents ( } \% \\
\text { of GDP) }\end{array}$ & 805 & 5.97 & 8.25 & 0.00 & 58.00 \\
\hline $\begin{array}{l}\text { Labour participation rate, total } \\
(\% \text { of total population ages } \\
15+)\end{array}$ & 546 & 66.57 & 8.13 & 49 & 86.1 \\
\hline $\begin{array}{l}\text { Gross capital formation ( } \% \text { of } \\
\text { GDP) }\end{array}$ & 733 & 26.67 & 8.83 & 5.18 & 70.23 \\
\hline $\begin{array}{l}\text { Mobile cellular subscriptions } \\
\text { (per } 100 \text { people) }\end{array}$ & 799 & 15.61 & 31.34 & 0.00 & 195.57 \\
\hline $\begin{array}{l}\text { Inflation, consumer prices } \\
(\text { annual } \% \text { ) }\end{array}$ & 736 & 7.69 & 13.16 & -9.07 & 268.15 \\
\hline $\begin{array}{l}\text { Labour force with formal } \\
\text { (primary, secondary and } \\
\text { tertiary) education ( } \% \text { of total) }\end{array}$ & 105 & 25.42 & 10.81 & 3.00 & 57.10 \\
\hline $\begin{array}{l}\text { KOF index of globalization (0- } \\
100)\end{array}$ & 775 & 45.7961 & 18.6541 & 13.66 & 90.00 \\
\hline
\end{tabular}

Notes: Annual data from 1980 to 2010 for 26 countries in East Asia and the Pacific and SouthAsia are used; the names of the countries included in the analysis are given in Appendix 2.

Source: Dreher (2006) for the KOF index of globalization; the World Bank, WDI online database for all the other variables.

Appendix 4: Correlation Matrix

\begin{tabular}{|c|c|c|c|c|c|c|c|c|c|}
\hline & $g d p p c p$ & agland. & nrents & lprate & $g \subseteq Q R$ & musers & inflat $\sim n$ & lfedu & kofundex \\
\hline gdppCP & 1.000 & & & & & & & & \\
\hline agland & -0.258 & 1.000 & & & & & & & \\
\hline nrents & -0.467 & 0.255 & 1.000 & & & & & & \\
\hline lprate & 0.221 & -0.044 & 0.214 & 1.000 & & & & & \\
\hline$g C a P$ & 0.171 & -0.257 & -0.346 & 0.010 & 1.000 & & & & \\
\hline musers & 0.499 & -0.105 & -0.145 & -0.003 & -0.007 & 1.000 & & & \\
\hline inflation & -0.151 & 0.020 & 0.045 & -0.192 & -0.167 & -0.237 & 1.000 & & \\
\hline lfedu & 0.6677 & 0.0554 & -0.499 & -0.059 & -0.039 & 0.2771 & -0.003 & 1 & \\
\hline kofindex & 0.777 & 0.0877 & -0.100 & 0.2539 & -0.11 & 0.4634 & -0.229 & 0.5722 & 1 \\
\hline
\end{tabular}

Notes: $g d p p c p=$ GDP per capita, PPP (constant 2005 int'l \$); agland= Agricultural land (\% of land area); nrents = Total natural resources rents (\% of GDP); lprate= Labour force participation rate, total (\% of total population ages 15+); gcap= Gross capital formation (\% of GDP); musers= Mobile cellular subscriptions (per 100 people); inflation=Inflation, consumer prices (annual \%); lfedu=Labour force with formal (primary, secondary and tertiary) education (\% of total labour force); kofindex = KOF index of globalization (0-100); annual data from 1980 to 2010 for 26 countries in East Asia and the Pacific and SouthAsia are used; the names of the countries included in the analysis are given in Appendix 2.

Source: Dreher (2006) for the KOF index of globalization; the World Bank's WDI online database for all the other variables.

\section{ABOUT THE AUTHORS}

Dr. Pramila Neupane is a Lecturer at the Foreign Language Center of University of Tsukuba, Japan. She holds Ph.D. in International Studies focusing educational development from Waseda University, Japan. Her research focuses on socioeconomic issues in education in developing countries. Email: neupane.pramila@gmail.com

Dr. Jeet Bahadur Sapkota is an Assistant Professor at the Graduate School of Humanities and Social Sciences of University of Tsukuba, Japan. He holds Ph.D. in International Studies focusing economics development from Waseda University. His research interests revolve around globalization, human development and rural infrastructure. Email: jbsnepal@gmail.com 